\title{
Islanders contest report on nuclear risks
}

[LONDON] A war of words has broken out between politicians on the island of Guernsey in the English Channel and officials at Britain's National Radiological Protection Board (NRPB) over the board's report on the risks to the island from two French nuclear facilities 15 miles away.

The report concludes that radiation doses to islanders from nuclear reactors at Flamanville and a fuel reprocessing plant at Cap de la Hague are not large enough to justify emergency countermeasures.

But many members of the island's 57strong parliament - known as the States supported by environmentalist groups such as Greenpeace, say that the report's content does not support such a conclusion.

Drawing on comments from an independent peer review, they claim the report is poorly researched and relies excessively on data from the French nuclear industry. They claim that it fails to address the implications for the island's 60,000 population of a 'worstcase scenario', such as a Chernobyl-style nuclear accident, only assessing smaller scale accidental releases of radioactivity.

One of the external reviewers, Philip Day, reader in chemistry at the University of Manchester, says the report is "seriously hampered" by lack of data. He adds: "Clearly if only trivial accidents are considered, then only trivial results are likely to ensue." He also raises "doubts as to the accuracy and completeness of the discharge data", claiming the omission of important radionuclides.

Last week, States members invited the NRPB to explain its research methodology at a public meeting. Some members, such as Roland Ogier, want the NRPB to commission new research based on independent data sources, or to reimburse the States the $\mathfrak{£} 35,000$ (US $\$ 56,000$ ) consultancy fee.

Meanwhile others, such as Jean Pritchard and 19 of her colleagues, have put their names to a letter to Dominique Voynet, the French environment minister, asking for reassurances that the nuclear facilities are safe. "We've waited two years for this report," says Pritchard. "We can't keep having reports if they don't answer our questions."

The prospect of the letter to Voynet is thought to have made the British government nervous, as Britain does not want to be seen interfering with or criticizing France's nuclear activities. Pritchard acknowledges that the letter may land the signatories in trouble as Channel Island politicians are not allowed to deal directly with the French authorities. All official communication takes place through the UK Home Office.

The NRPB report was published at the end of last month. It was commissioned two years ago to assess the safety claims of COGEMA, which runs the fuel reprocessing

\section{Brazil to sequence 'first plant pathogen'}

[SÃo PAULO] The creation of a network of laboratories in São Paulo state, Brazil, to sequence the complete genome of a microorganism was announced last week by the Foundation for the Support of Research of the State of São Paulo (FAPESP), the state funding agency.

The Organisation for Nucleotide Sequencing and Analysis will first tackle the bacterium Xylella fastidiosa, the causal agent of many economically important plant diseases, particularly citrus variegated chlorosis, which poses a major threat to São Paulo's orange cultivation. This is thought to be the first plant pathogen genome to have been sequenced.

Citrus variegated chlorosis, first reported in 1987, has been found only in Brazil and Argentina. São Paulo and Florida are the two most important citrus-growing areas in the world, São Paulo producing 87 per cent of Brazil's - and 30 per cent of the world's - citrus crop. According to FAPESP, the total cost of the project is US\$11.6 million, to be spent over two years. Sequencing completion is predicted by 2000 .

Xylella fastidiosa was chosen because sequencing might help in the control of the pest, with obvious gains to the state's economy. It will also help to forge links between research centres and the private sector, which is contributing to the cost of the project.

The state says that it is keen to create a network of laboratories that will "significantly increase the number of laboratories in the state capable of using modern molecular biology techniques".

The project will be overseen by a fivemember steering committee consisting of three international experts in genome sequencing and two researchers from São Paulo state. Two of the experts, André Goffeau of the University of Louvain in Belgium and Steve Oliver of the University of Manchester Institute of Science and Technology, helped to set up the project, and were also involved in the sequencing of the Saccharomyces cerevisiae genome.

The committee will select one laboratory to house a bioinformatics centre. Two large central sequencing laboratories will be chosen to generate a large part of the sequence data. These laboratories will also act as training and support centres for other members of the network. Ricardo Bonalumé facility at Cap de la Hague. The company had told the States in 1995 that there were no significant risks of radioactive contamination beyond a five-kilometre radius of Cap de la Hague, a conclusion that is effectively confirmed by the NRPB.

The NRPB is standing by its document. Stephanie Haywood, the report's editor, acknowledges that the report relies on data from COGEMA on accidental release of radiation. But she says that the data conform to standards laid down by the European Atomic Energy Agency, Euratom.

In the report, Haywood and colleagues included an assessment of radiation doses to the Guernsey population from everyday atmospheric release, from the marine transport of waste, as well as from three potential scenarios of accidental release.

Haywood adds that the criticism that NRPB did not conduct original research on accidental release is unjustified, as the nature and scope of the study had been agreed with the States. She says that States members had been made aware "from the beginning" that the NRPB's expertise was limited to assessing the health risks of radiation. She says a Chernobyl-style accident was not part of the study as the NRPB is not qualified to assess the probability and implications of a major nuclear accident, and that such information has not been released by the site operator.

Ogier, who sent the report for external peer review, says he is "baffled" by such an admission. It appears, he says, that the NRPB has used COGEMA to investigate the safety claims made by that very source.

"I may not be a scientist," he says, "but it is not difficult to tell that the NRPB did not even try and ask the right questions. Some of the report is just O-level physics. Other parts lack a proper analysis and discussion."

The NRPB is supported by the island's Civil Defence Committee, a group comprising members of the States as well as other island officials, which is responsible for advising on nuclear safety. John Langlois, the committee's president and a member of the States, says that if the data supplied are acceptable to institutions such as Euratom, they should be good enough for members of the States of Guernsey.

Ogier says that the issue is of wider significance. "In the past, we've had a very patrician attitude to government - though this is slowly changing." In public, he says, the official line on issues such as the nuclear facilities has always been that there is no risk. "This is done to safeguard interests such as the tourist industry." But, behind the scenes, Ogier says officials are working furiously to establish the truth. Now "there needs to be some admission that there are grey areas". Ehsan Masood 